
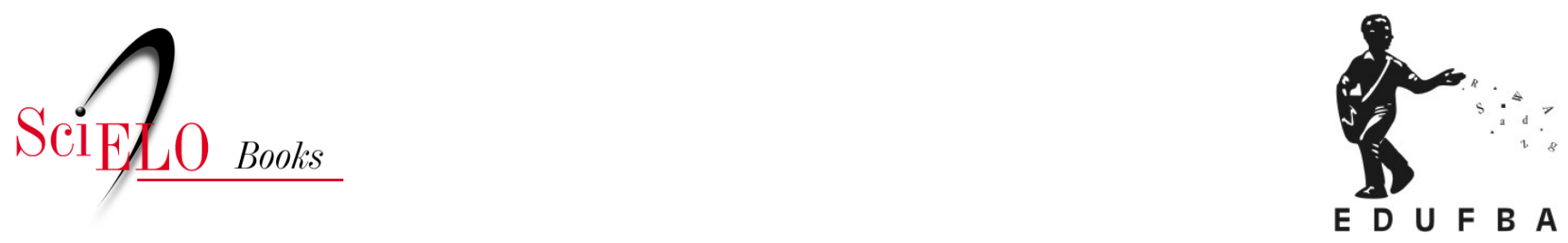

\title{
Capoeira Angola
}

\author{
Hellio Campos
}

\section{SciELO Books / SciELO Livros / SciELO Libros}

CAMPOS, H. Capoeira Angola. In: Capoeira regional: a escola de Mestre Bimba [online]. Salvador: EDUFBA, pp. 37-60. ISBN 978-85-232-1727-3. Available from: doi: 10.7476/9788523217273.0006. Also available in ePUB from: http://books.scielo.org/id/p65hq/epub/campos-9788523217273.epub.

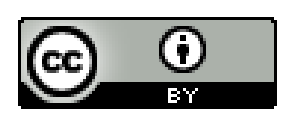

All the contents of this work, except where otherwise noted, is licensed under a Creative Commons Attribution 4.0 International license.

Todo o conteúdo deste trabalho, exceto quando houver ressalva, é publicado sob a licença Creative Commons Atribição 4.0.

Todo el contenido de esta obra, excepto donde se indique lo contrario, está bajo licencia de la licencia Creative Commons Reconocimento 4.0. 


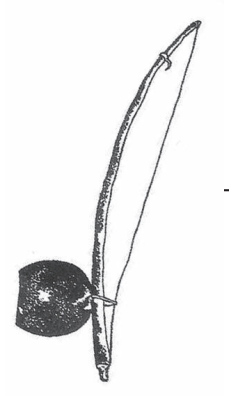

Capoeira Angola

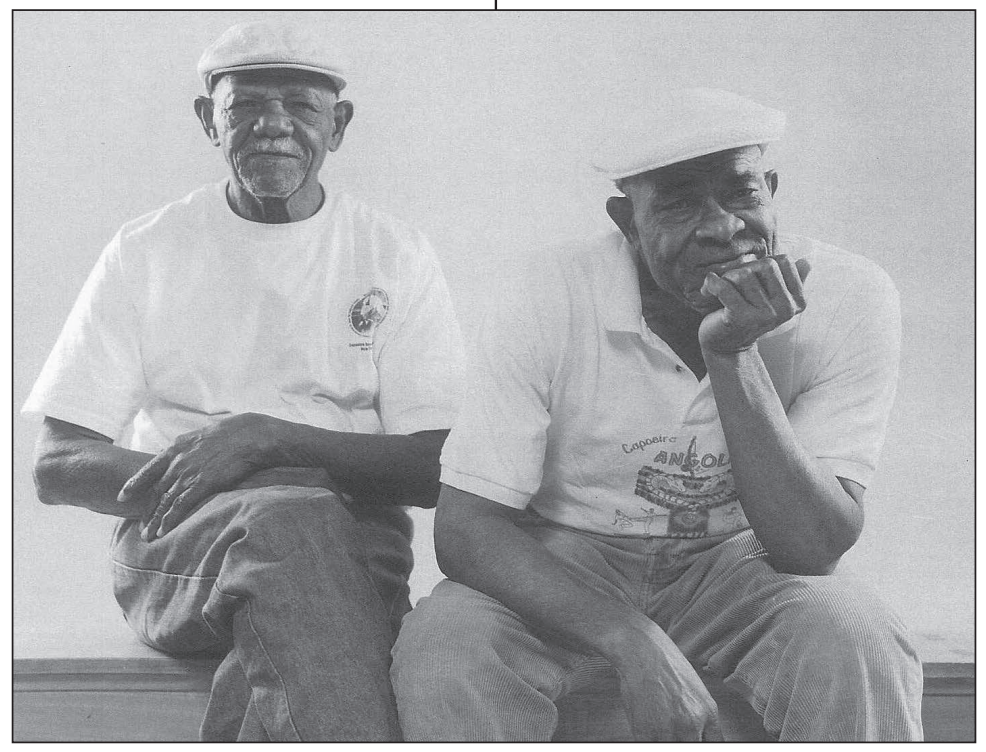


screver sobre a Capoeira Angola é um desafio interessante, pois nos deparamos
com estilo de capoeira que não tem um criador, e muito menos publicações de referência que possam sustentar uma teoria. Muitos são os mestres que transitam nessa atividade, trazendo consigo uma gama de informações que lhes foram passadas pela oralidade, de mestre para mestre, cada um contando as suas histórias, suas verdades, sua vida.

Também, nesse cenário, encontramos famosos mestres oriundos da capoeira urbana e da capoeira rural, e aqui destacamos a capoeira praticada no recôncavo baiano. Todos eles trabalham em linhas diferentes de capoeira. São eles: Cobrinha Verde, Pastinha, Waldemar da Liberdade, Canjiquinha, Samuel Querido de Deus, Juvenal, Espinho Remoso, entre outros.

Existem dúvidas sobre a origem da Capoeira Angola. Há quem afirme que ela foi trazida para o Brasil pelos escravos africanos que aqui aportaram oriundos do tráfico negreiro. Outros estudiosos acreditam que é uma manifestação africana, uma criação dos africanos no Brasil e um produto do seu modo de vida nas senzalas, no meio rural e mesmo urbano.

Acredita-se que é originária de um ritual de passagem: a Dança da Zebra ou N'golo, originária do povo "Mucope", do Sul de Angola, que era um acontecimento marcado pela "Efundula" (festa da puberdade), uma cerimônia decisiva e violenta que marcava a passagem da adolescência para a vida adulta, estando o jovem pronto para o casamento. Nesta iniciação, os vencedores tinham como prêmio o direito de escolher as meninas da tribo que ficavam moças. Segundo Mestre Bola Sete, "ainda hoje, existe um ritual semelhante na África, em Katagun (Nigéria)" (1989, p. 21).

Gildo Alfinete ${ }^{1}$, um dos alunos mais importantes de Pastinha, define a Capoeira Angola como "uma das mais ricas manifestações da cultura popular negra da Bahia. Além de reunir elementos de música, dança, poesia e artes cênicas, carrega os fundamentos africanos de uma relação humana solidária".

Para Pires, "[...] a Capoeira Angola é tida como tradicional, não porque obedeça a uma lógica da capoeira praticada pelos predecessores diretos de Mestre Pastinha, mas, sim, pelo fato de a Capoeira Angola ter algo a ver com a praticada pelos africanos" (2002, p. 84). 
Atribui-se o nome de Capoeira Angola pelo motivo de serem os primeiros e numerosos escravos africanos a chegarem ao Brasil e em especial na Bahia, os negros bantos, naturais de Angola. Na atualidade, especula-se que o nome Capoeira Angola surgiu também para se contrapor ao da Capoeira Regional.

A Capoeira Angola tem várias linhagens, porém o seu grande defensor é Vicente Joaquim Ferreira Pastinha (Mestre Pastinha), conhecido como o Guardião da Capoeira Angola. Pastinha nasceu no dia 05 de abril de 1889, na cidade do Salvador e morreu em 13 de novembro de 1981. Sua vida foi recheada de histórias e dificuldades, tendo se agravado com a perda da visão em 1967, a qual o acompanhou até o último dia de vida.

Elegemos Mestre Pastinha para guiar nosso estudo sobre a Capoeira Angola, justamente pela sua filosofia de vida, pelo seu trabalho de resistência em prol do reconhecimento da capoeira, pelos seus seguidores e pela sua liderança.

Pires afirma que "Mestre Pastinha desempenhou um papel de verdadeiro líder, orientando politicamente os capoeiristas, estimulando-os para que formassem um grande centro de Capoeira Angola" (2002, p. 81). Defendia, ainda, a unidade em torno da Capoeira Angola e, especialmente, a reconhecia como um tipo de esporte brasileiro.

Mestres Noronha (1993, p. 17), Bola Sete (1989, p. 29) e Decanio (1996, p. 20-21) asseveram sobre a fundação, em 1941, do primeiro Centro de Capoeira Angola do Estado da Bahia, localizado na Ladeira de Pedra, no Jingibirra, Bairro da Liberdade, em Salvador. Segundo eles, o centro foi criado por grandes mestres, como Daniel Coutinho (Noronha), Livinio Diogo, Totonho de Maré, Amorzinho, Raimundo Aberrê, Percílio, Geraldo Chapeleiro, Juvenal Engraxate, Geraldo Pé de Abelha, Zehi, Feliciano Bigode de Ceda, Bonome, Henrique, Cara Queimada, Onça Preta, Cimento, Agimiro Grande, Olho de Pombo, Estivador, Antônio Galineu, Antônio Burça, Lúcio Pequeno, entre outros. Nessa oportunidade, Mestre Pastinha foi apresentado por Aberrê, justificando a morte de Amorzinho Guarda, por decisão entregou a Mestre Pastinha a roda, que com esforço a registra e eleva, dando uma nova cara à Capoeira Angola, o que Mestre Noronha enaltece dando graças ao bom Deus e dizendo ser Pastinha um espírito de luz.

Mestre Pastinha passa a ser então uma liderança, o responsável por organizar a Capoeira Angola, aglutinar os mestres em busca de uma unidade e objetivos comuns. Outras iniciativas de organização aconteceram, em 1944, no Centro Operário da Bahia e, em 1949, quando foi procurado por Ricardo, ex-instrutor de luta da Guarda-Civil para reorganizar o centro de Capoeira. Diante dessa incumbência, fundou e registrou, em 1952, o Centro Esportivo de Capoeira Angola, que inicialmente se estabeleceu no Largo do Pelourinho $\mathrm{n}^{\circ}$ 19 e, posteriormente, na Rua Gregório de Mattos n ${ }^{\circ} 51$.

Pires sustenta que Pastinha teve como meta expandir a Capoeira Angola, querendo que fosse conhecida pela população baiana, como um esporte, e não "ficasse como uma prática cultural típica da escravidão, quando, segundo ele, a violência entre os praticantes teria chegado aos extremos" (2002, p. 82). 
Decanio, no seu livro "A herança de Mestre Pastinha" (1996), ressalta poeticamente o seu valor:

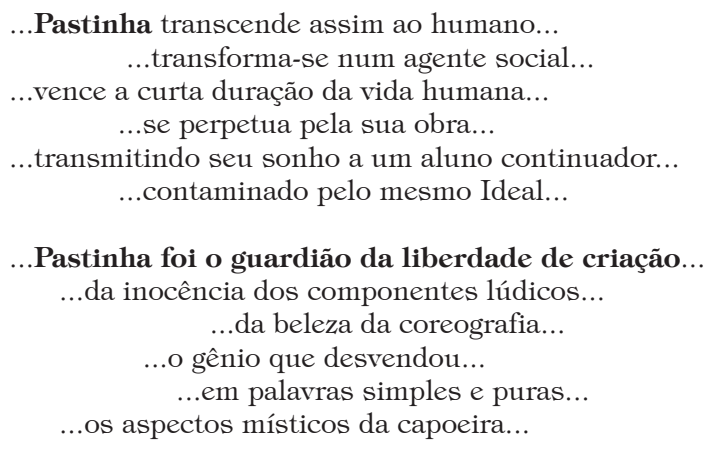

Mestre Pastinha é conhecido como um filósofo bem-humorado da capoeira e muitas frases e momentos de lucidez são atribuídos à sua pessoa, o que denota o seu carinho, dedicação e expressivo amor pela Capoeira Angola.

Decanio assim escreve:

Pastinha proclama...

...a soberania do espírito sobre o corpo e a razão...

...a presença do divino que habita o temporal.. ...integrando o SER...

...pela primeira vez encontramos..

...um Mestre de capoeira...

...preocupado com os aspectos espirituais...

...metafísicos..

...dos capoeiristas...

...abrindo o caminho para o uso pedagógico...

...e terapêutico da nossa arte-e-manha.

...reconhece a presença da parte espiritual...

...como componente do comportamento dos capoeiristas...

...desfazendo os preconceitos de capadócio...

...de malandro... de desordeiro...

...com o qual a classe dominante tentou estigmatizar...

...e sequestrar a capoeira e seus praticantes...

...a capoeira baiana é.. ...sobretudo, um modo de viver... ...uma filosofia baseada na liberdade individual... ...na alegria.. ...no respeito.. ...na cooperação... ...na camaradagem.. ...no espírito comunitário.. ...integrando assim o homem na sociedade...

Mestre Pastinha se refere à Capoeira Angola como a legítima capoeira, justificando ser ela originária direta dos africanos aportados no Brasil. Chama a atenção de ser ela uma luta diferente, uma luta de resistência baseada nos golpes e contragolpes que servem de uma excelente defesa pessoal. Falando de sua utilização no cotidiano, assim se refere: "não aprender a capoeira para a valentia, mas, sim, para a defesa de sua integridade física, pois um dia pode ter necessidade de usá-la para sua defesa. Cuja defesa é contra qualquer 
agressor, que lhe venha ao encontro com navalha, faca, foice e outras armas" (DECANIO, 1996, p. 37).

Com esta frase, Mestre Pastinha mostra a grandeza da Capoeira Angola na sua prática diuturna, retratando a capoeira praticada no início do século XX, quando a capoeira foi violentamente perseguida pela sociedade e pela polícia. O capoeirista tinha que defender, a qualquer custo, sua integridade física, emocional e moral; defender uma causa muito maior, seu povo, seus costumes e sua cultura.

Sobre o ensino da capoeira, Pastinha assim se refere:

Com fé e coragem para ensinar a mosidade (sic) do futuro estou apenas zelando para esta maravilhosa luta que é deixa (sic) de herança adquirida da dança primitiva dos caboclos, do batuque, e candobré (sic) originada pelos africanos de Angola ou Gejes; muitos admira (sic) essa belíssima luta quando os dois camaradas joga (sic) sem egoísmo, sem vaidade; é maravilhosima (sic), e educa (DECANIO, 1996, p. 39).

Pastinha tinha uma preocupação toda peculiar com o ensino-aprendizagem da capoeira. Na citação acima, denota seu zelo com a educação, valorizando o companheirismo, o lúdico, a herança cultural e o deixar de lado as couraças pessoais da vaidade e do egoísmo e simplesmente vadiar na roda da capoeira.

Valorizava a capoeira em seus mais variados aspectos, afirmando que, dentro dos limites esportivos, a capoeira contribui indubitavelmente para o desenvolvimento físico e da saúde e que qualquer pessoa poderia praticá-la, pois não apresentava risco algum. E filosofava dizendo: "capoeira é para homem, menino e mulher"; "capoeira é tudo que a boca come". Ressaltava, com veemência: praticamente não há limite de idade para entrar numa academia de Capoeira Angola. Bastante elevado é o número de pessoas cuja idade ultrapassa os sessenta anos. São indivíduos que praticam esse esporte desde a juventude, possuindo uma invejável movimentação corporal, agilidade e flexibilidade de articulação que impressionam.

\section{A MANDINGA DO JOGO}

Definindo o jogo de capoeira, Pastinha assevera que o bom capoeirista lança mão de inúmeros truques para enganar e distrair o adversário. Dissimula, aparenta que se retira e se volta rapidamente, tentando surpreender. Pula de um lado para outro. Agacha-se, deita e se levanta desordenadamente. Avança e recua. Finge que está fora do jogo, que não está vendo o adversário, com a finalidade de atraí-lo para uma emboscada. Simula, gira e se contorce numa ginga maliciosa e desconcertante.

O capoeirista não tem pressa, observa o adversário, usa a visão periférica, sente o melhor momento para entrar e aplicar um golpe ou mesmo um contragolpe; prevê a saída, ginga sempre e está em constante movimento para aproveitar tudo o que o ambiente possa the proporcionar. 
Para Silva, o jogo de angola "é a arte simulada no jogo da vida, onde os Capuêiristas (sic) representam todas as passagens que a vida lhe (sic) oferece: da maldade a (sic) falsidade, da mandinga a (sic) inocência, do logro a (sic) astúcia e da ignorância à sabedoria, a forma peculiar de ser, de viver" (2003, p. 109).

A Capoeira Angola tem um número reduzido de golpes, mas nem por isso deixa de ser eficiente e perigosa enquanto luta. Mestre Bola Sete diz que os principais golpes da Capoeira Angola são desferidos com os pés e as partes dos mesmos com o objetivo de atingir o adversário. Afirma também que existem dúvidas quanto aos nomes dos golpes e suas variações. Justifica este fato, reportando-se a um grande número de mestres que batizavam os golpes com diferentes nomes e aos muitos golpes tidos como primitivos que foram modificados ou desapareceram, ao mesmo tempo em que novos movimentos foram criados e aperfeiçoados (1989, p. 43).

A ginga é a característica marcante do jogo da capoeira e identifica cada capoeirista, seu estilo, manha, malícia, habilidade e competência.

Para Mestre Bola Sete,

Ginga - É o principal movimento da Capoeira. Na ginga o capoeirista poderá defender-se com o auxílio das mãos e dos braços, negaceando em várias posições, deslocar-se para qualquer posição permitindo-lhe uma melhor posição para a defesa, o ataque e o conta-ataque além da utilização do "floreio", que consiste no jogo de corpo, onde o capoeirista, como o nome já diz, utiliza movimentos corporais, com o intuito de distrair o adversário para melhor aplicar-lhe o golpe (1989, p. 44).

Mestre Itapoan, abordando o ensino da ginga na Capoeira Regional, ressalta que Mestre Bimba insistia que o aprendizado da ginga era o ponto crucial, a parte mais importante no ensino da capoeira. "A ginga é o ponto de partida de todas as aquisições futuras. É a posição 'fundamental' do capoeirista". Mestre Itapoan afirma ter assistido Mestre Bimba repetir muitas vezes que "a ginga é a alma do capoeirista" (1994, p. 80). É importante frisar que não existem duas gingas iguais; ela depende da habilidade motora e da interiorização pessoal, pelas quais aflora o sentimento, a emoção e o amor, transmudados em movimento negaceado único.

A roda de Capoeira Angola constitui-se em um dos momentos mais marcantes, representando o coroamento da inserção no mundo capoeirístico e uma das ocasiões mais ricas de aprendizado.

Para Costa, a roda representa um aspecto profundo, ritualístico, uma maneira de harmonizar e equilibrar as formas e energias presentes na capoeira: a democracia prevalece, todos os participantes têm importância funcional, não existindo privilégios, configurando, assim, uma contribuição harmônica, "todos podem jogar sua voz" e consequentemente todos são igualmente importantes no contexto da roda de capoeira (1993, p. 113).

A roda é uma figura geométrica na qual se pressente circular uma grande quantidade de energia devido ao somatório das energias presentes e ao seu movimento constituído pelos toques, cânticos e ritmos comandados pelo berimbau, que parece atrair forças da natureza 
cósmica, emanando uma vibração indescritível, a ponto de muitos capoeiristas afirmarem entrar num estado de transcendência e liberdade.

Para jogar na roda da Capoeira Angola, o capoeirista precisa conhecer o ritual. Inicialmente, tem que observar o conjunto musical formado por três berimbaus de tamanhos e sonoridades diferenciadas: o maior, chamado de gunga ou berra-boi, que marca o toque principal, normalmente tocado pelo mestre; o médio, denominado de viola, que faz acompanhamento ao primeiro; e o terceiro, o menor, conhecido como pequeno ou violinha, que marca os tons distintos dos demais, criando uma riqueza de harmonias através dos repiques. Os outros instrumentos que compõem a bateria são dois pandeiros, atabaque, agogô e reco-reco.

O ritual determina que os dois capoeiristas, quando dispostos a vadiar, devem se agachar "ao pé do berimbau" e esperar o canto da ladainha, geralmente entoado pelo mestre que está tocando o gunga, seguido pelos berimbaus médio e violinha e, por fim, os pandeiros e demais instrumentos. Durante o canto de entrada, os capoeiristas devem aguardar o momento de sair para o jogo através da senha inserida na música: "que o mundo dá"; os jogadores se benzem fazendo o sinal da cruz e demonstram suas habilidades, em exercícios preparatórios e orações, pedindo para que o jogo lhes seja favorável. Os toques mais praticados durante a ladainha (louvação) são Angola e São Bento Pequeno. Na sequência da roda é a vez do canto corrido que pode ser acompanhado pelos toques de São Bento Grande ou Angola Dobrada, dentre outros; a roda segue em movimento contínuo, com os capoeiristas realizando a compra do jogo, a chamada e a volta ao mundo.

O berimbau dita o ritmo do jogo e o toque de angola revela um jogo baixo e de meia altura, que tem como objetivo uma contenda difícil e viril. O São Bento Grande indica um jogo lento, porém astuto, manhoso e competitivo. O toque de São Bento Pequeno tem um ritmo mais rápido e sugere um jogo educativo, técnico, privilegiando os golpes desequilibrantes, traumatizantes, projeções e fundamentos aprimorados de esquivas. A cavalaria é um toque tradicional de aviso que tende a imitar um trote de cavalos, lembrando o barulho da cavalaria na época da escravidão. Os mestres costumavam tocar a cavalaria quando pressentiam a aproximação de um estranho no ambiente da capoeira.

A indumentária é uma questão bastante discutida no meio capoeirístico e o uso do traje branco é o mais aceito, por lembrar a tradição dos antigos capoeiristas. Mestre Bola Sete assim se reporta:

Em nossa terra, os capoeiristas do passado, nos dias de trabalho, usavam camisa de alinhagem, urucubaca ou bulgariana, calça bem folgada de pantalona ou qualquer outro tecido barato, arregaçada quase até o joelho, chinelos de chagrin ou descalços. Nos domingos, trajavam-se com mais esmero. Vestiam a "domingueira", que geralmente era de linho branco, amarravam um lenço de esguião de seda no pescoço, que tinha como finalidade proteger do suor o colarinho da camisa, além de servir como defesa contra navalha, pois, como sabemos, a navalha não corta seda pura; sapato de bico fino e uma pequena argola de ouro na orelha esquerda, que era uma característica dos negros Angola (1989, p.175).

A roupa branca tem um significado todo especial, representa a maestria do bom capoeirista que, ao jogar capoeira, deveria sair ileso, com veste impecável, sem estar amarrotado 
e com a alvura incontestável, mostrando sua ligeireza, astúcia e mandinga de não estar carimbado pela sujeira desferida através de um golpe dado pelo adversário.

É importante registrar que outros mestres - a exemplo de Valdemar da Liberdade, João Pequeno, João Grande, Traíra, Totonho de Maré, Cobrinha Verde, Caiçara, Canjiquinha, Paulo dos Anjos, Curió, Gildo Alfinete, Augustão, Mala, Gato, Bom Cabrito, Vermelho Afonjá, dentre outros — fizeram e fazem acontecer a Capoeira Angola, nas suas mais variadas vertentes e especificidades, resgatando a tradição, fortalecendo o convívio, a pesquisa e a expansão. Todos têm - ou tinham - como principal referência a figura de Mestre Pastinha — "o guardião da Capoeira Angola".

\section{DOIS JOÕES: OS ALUNOS SEGUIDORES}

Mestre Pastinha sempre foi tido como um filósofo da capoeira. Criou e incutiu refinados modos, finas maneiras de tratar o ensino da arte de capoeirar, fortalecida pelo aspecto espiritual, da liberdade e da igualdade. Uma frase presente nas rodas de capoeira parece afirmar sua ideologia: "capoeira é pra homem menino e mulher, só não aprende quem não quer".

Ele sempre desejou a expansão da Capoeira Angola, pensava em vê-la no mais alto podium, difundida na sociedade e por isso tinha uma especial preocupação com a sua continuidade, filosofando em seus manuscritos: "quando as pernas fazem miserê: metafísica e prática da capoeira". No seu dizer simples, ele dá o recado, dizendo que reconhece seus pupilos e sabe exatamente a hora em que as pernas são capazes de caminhar por conta própria, o momento de atribuir-lhes responsabilidades, dar força para o gavião voar em busca de novas experiências. Por isso, na década de 1970 e início da de 1980, quando Pastinha já passava por dificuldades, inclusive já com a cegueira, nomeou dois de seus alunos para darem continuidade ao seu trabalho, assim dizendo:

Eles (João Pequeno e João Grande) serão grandes capoeiras do futuro e para isso trabalhei e lutei com eles e por eles. Serão mestres mesmo, não professores de improviso, como existem por aí e que só servem para destruir nossa tradição que é tão bela. A esses rapazes ensinei tudo o que sei, até mesmo o pulo do gato (DIÁRIO DE NOTÍCIAS, 3. out. 70).

Mestre Pastinha enaltecia seus alunos, afirmando "na minha academia tem dois meninos, todos dois se chamam João: um é cobra mansa, o outro é gavião. Um joga no ar, o outro enroscado pelo chão". Esse dois Joões não decepcionaram e na atualidade são considerados os herdeiros diretos de Mestre Pastinha: um fez sua vida na Bahia e o outro voou para longe, Nova York.

\section{Mestre João Pequeno de Pastinha}

João Pereira dos Santos nasceu no dia 27 dezembro de 1917, na cidade de Araci, interior do Estado da Bahia, localizada entre as Cidades de Serrinha e Tucano. Filho de vaqueiro que o fez ter muitas moradas, pois seu pai era impelido a trabalhar em fazendas, o que exigia constantes mudanças de endereço. 


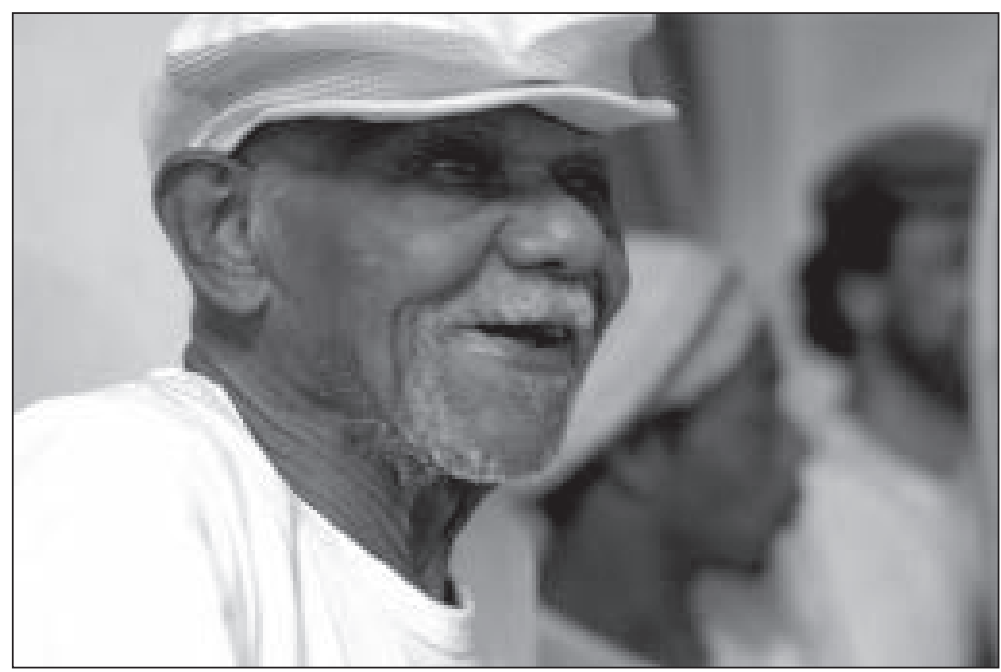

Quando conheceu Mestre Pastinha, já praticava capoeira nas ruas de Salvador, tendo os primeiros contatos com a capoeira através de Barbosa e Juvêncio; porém, foi Pastinha quem o amparou e ensinou os segredos da Capoeira Angola. Nas suas palestras, ele lembra com saudade da convivência e da amizade de Pastinha e destaca um momento em que o mestre disse para ele: "João tome conta disto, que ela vai morrer". Uma responsabilidade e tanto, que João Pequeno faz valer a cada minuto de sua vida.

Decanio $^{2}$, em entrevista no documentário $O$ Velho Capoeirista, diz que, para ele, João Pequeno é o aluno mais importante de Pastinha e ressalta sua importância histórica tão significativa quanto a de Mestre Pastinha, pois se "Pastinha instalou, iniciou o movimento de retorno da ludicidade na capoeira, João Pequeno deu continuidade à obra", por ser um aluno mais constante e fiel aos ensinamentos do seu mestre e que "permanece teimosamente vivo jogando capoeira aos oitenta anos de idade".

Pastinha colocou João Pequeno para ajudar nas aulas, logo que este começou a participar da academia de Capoeira Angola, chegando mesmo a ser uma espécie de contramestre, fato este comprovado pelo Mestre Curió. Nesta função de colaborador, muitos capoeiristas passaram por suas mãos, inclusive João Grande, que foi levado à academia pelo próprio João Pequeno.

Em 1966, sob a liderança de Mestre Pastinha, João Pequeno participou do $1^{\circ}$ Festival Mundial de Arte Negra, em Dakar Senegal, juntamente com João Grande, Gato, Roberto Satanás, Camafeu de Oxóssi e Gildo Alfinete.

João Pequeno participou do Programa Nacional de Capoeira da Secretaria de Educação Física e Desporto do Ministério de Educação (SEED/MEC), em 1990, tendo gravado o seu primeiro disco solo, à época um LP, fruto do Projeto Oficina do Movimento do Liceu de Artes e Ofícios da Bahia.

João Pequeno foi um elemento importante na (re)estruturação da Capoeira Angola, justamente no momento em que Pastinha não tinha mais forças suficientes para tocar seu 
projeto; João Pequeno, nessa oportunidade, aflorando no final dos anos setenta, organiza sua academia e lá começa a traçar os caminhos para um novo projeto da Capoeira Angola.

Sua academia está localizada no Forte Santo Antônio Além do Carmo, sendo o primeiro mestre a se instalar naquela localidade, lutando cotidianamente contra o descaso das autoridades e os preconceitos, e sendo constantemente ameaçado de despejo.

Outrossim, a sua academia passou a ser referência para capoeiristas de todo o mundo, os quais se dizem encantados com a capoeira ali praticada, sendo a simplicidade dos movimentos, o método de ensino, o aconchego, a boa conversa, os sábios ensinamentos do mestre a sua marca registrada.

Mestre João Pequeno tem levado a Capoeira Angola para muitos lugares, onde quer que seja, no Brasil ou fora dele, ministrando palestras, cursos, workshops, seminários e participando dos batizados e troca de cordéis de vários grupos de capoeira. É um divulgador incansável da Capoeira Angola.

Ele tem recebido muitas homenagens, dentre as quais destacamos o Título de Cidadão da Cidade do Salvador, em 3 de setembro de 1998, concedido pela Câmara Municipal de Salvador. Nessa ocasião, em entrevista à TV Bahia, ele se expressou dizendo enfaticamente ser uma pessoa feliz, reconhecida e agradecida, pois se considerava um "doutor na capoeira". Capinam ${ }^{3}$, poeta e compositor baiano, assim se referiu: "Salvador fez um gesto mais que necessário, oportuno", pois, no seu entendimento, a capoeira baiana não tem tantos mestres desse quilate para manter viva a tradição, e que essas homenagens são fundamentais no sentido de manter em evidência a nossa história, nossa cara e nossa identidade.

Duas outras homenagens merecem menção. São elas: a Ordem do Mérito dos Palmares, em 16 de setembro de 2002, e a de Doutor Honoris Causa, outorgada pela Universidade Federal de Uberlândia, em 18 de dezembro de 2003. No momento, tramita o projeto de reconhecimento para a outorga do título de Doutor Honoris Causa pela Universidade Federal da Bahia.

Lembro-me perfeitamente da participação de João Pequeno no seminário comemorativo dos vinte anos da FACED/UFBA (Faculdade de Educação da UFBA), quando o mesmo, na sua simplicidade, palestrou sobre a Capoeira Angola e encantou todos os presentes. Após o evento, fui procurado por vários colegas que se disseram impressionados com a desenvoltura, a tranquilidade, a segurança e o bom humor com que João Pequeno se apresentou, conquistando todos os presentes.

João Pequeno, como tantos outros mestres de capoeira, se ressente de um reconhecimento concreto, por parte das autoridades baianas, pois, ao mesmo tempo que a Câmara Municipal de Salvador lhe concede um título dessa envergadura, ameaçam despejá-lo do Forte do Santo Antônio Além do Carmo, sem levar em consideração a sua importância histórica no conjunto da revitalização do Centro Histórico de Salvador. Para Decanio, a "capoeira deu ao Forte de Santo Antônio um cunho de respeito", e a presença de João Pequeno e sua Capoeira Angola desperta a atenção dos governantes. 
A importância de João Pequeno na capoeira não se resume ao fato dele ter sido aluno de Mestre Pastinha, mas, sobretudo, por ser um homem de fé, de hábitos simples, que denotam o seu despojamento da vaidade, sempre preocupado em elevar a sua arte ao mais alto patamar de reconhecimento, como um instrumento de cidadania e, por esse motivo, nunca se furtou a comparecer em qualquer evento, dando sua contribuição baseada na sua verdade, valor e limitações, como qualquer outro mortal.

Sua preocupação com o ensino da Capoeira Angola sempre se pautou no bem-estar dos seus alunos, primando por um método fundamentado no prazer e na ludicidade, valorizando os saberes culturais, o jogo da camaradagem e, principalmente, a liberdade de escolha.

\section{Mestre João Grande: o embaixador da Capoeira Angola}

Considerado um "gavião" por seu Mestre Pastinha, João Oliveira dos Santos, "João Grande", um negro simpático e capoeirista, bate asas, levantando vôo em direção aos Estados Unidos. O que parecia à primeira vista uma aventura, agora é uma realidade. Mestre João Grande está definitivamente radicado em Nova York, ministrando aulas de capoeira há quinze anos, na sua academia localizada no segundo andar de um prédio que fica na esquina da Sexta Avenida com a rua 14, próximo ao Village.

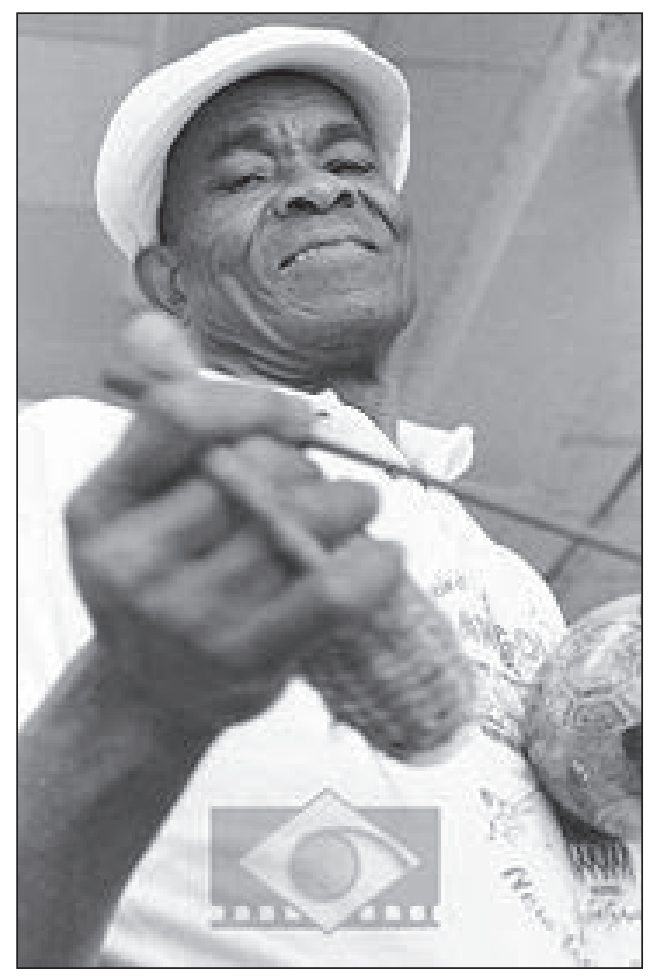


A experiência internacional começou em 1966, quando integrou a comitiva de Mestre Pastinha, representando o Brasil no $1^{\circ}$ Festival Mundial de Arte Negra em Dakar, Senegal. Logo, outras oportunidades vieram, como as excursões pelo Brasil, Europa, Ásia e África, integrando, desta feita, o elenco do Grupo Folclórico Viva Bahia, liderado pela folclorista Emília Biancardi.

João Grande nasceu em 15 de janeiro de 1933, na cidade de Itagi, situada no Litoral Sul da Bahia, a 407 km de Salvador. João é oriundo de família pobre e passou a infância e parte da adolescência na roça, contando ainda com um infortúnio que marcou a sua vida, ao perder sua mãe aos dez anos de idade, o que o forçou a trabalhar cedo nas fazendas da região. Na região, devido ao seu labor, ganhou o apelido de "João bate-estaca".

Aos vinte anos, veio para Salvador tentar a sorte e, chegando na "cidade grande", arregaçou as mangas e trabalhou para sobreviver: foi empregado doméstico, carregador, lavador de carros e biscateiro. Na capoeira, encontrou um alento, uma válvula de escape para suas angústias e, por esse motivo, não faltava às aulas e aos treinamentos, quando estava sempre disposto a capoeirar, o que lhe proporcionou tornar-se respeitado no meio capoeirístico.

João Grande conheceu Pastinha através de João Pequeno e de imediato se encantou com as histórias do famoso mestre, por isso chegava antes dos treinos para conversar, ouvir Pastinha, ouvir os conselhos e a filosofia da arte de capoeirar. Pastinha não foi econômico e como grande professor lhe transmitiu todos os ensinamentos da Capoeira Angola, até o "pulo do gato".

Mestre João Grande se destaca na Bahia pela sua forma de jogar, pela maneira simples de transmitir com entusiasmo o legado de Pastinha e por se sobressair nos grupos folclóricos baianos, como o Viva Bahia, o Ofonjá e o Moenda.

A exemplo de outros mestres baianos, João Grande também tem recebido muitas homenagens, sendo a primeira delas a "Medalha do Mérito Desportivo Nacional", concedida pelo Conselho Nacional do Desporto (CND), do Ministério da Educação, em fevereiro de 1990. Nessa solenidade, João Grande se expressou, dizendo: "esta é a maior homenagem que já recebi. Hei de semear capoeira por todos os lugares onde andar"4.

Cumprindo sua palavra, João Grande tem levado a capoeira para o mundo, não somente semeando a Capoeira Angola, mas acima de tudo semeando a cultura afro-brasileira, a língua portuguesa e divulgando o Brasil. Por esse incansável trabalho, em 1995, ele foi agraciado com o título de Doutor Honoris Causa pela Upsala College, em New Jersey, e, em 2001, foi condecorado com o National Heritage Fellowship Award, considerado o maior prêmio concedido pelo governo americano para as artes folclóricas, tradicionais e manifestações culturais. Esse prêmio é destinado àquelas pessoas que estão empenhadas na preservação e transmissão das tradições ancestrais.

João Grande ministrou aulas no Projeto Oficina do Movimento, do Liceu de Artes e Ofícios da Bahia, através do Programa Nacional de Capoeira, da Secretaria de Educação 
Física e Desporto do Ministério da Educação (SEED/MEC), o que lhe proporcionou o lançamento do primeiro disco de Capoeira da série "Capoeira Arte \& Ofício".

Mestre João Grande é um autêntico herdeiro de Pastinha, gosta de filosofar e é rigoroso no que tange aos rituais da capoeira. Diz ser a capoeira um mistério, pois considera que as manifestações advindas da cultura africana sempre trazem no seu bojo, na sua essência, os dogmas dos seus ancestrais.

Na atualidade, João é muito requisitado para cursos, palestras, seminários e batizados, por diversos grupos de capoeira, independentemente do estilo. Vive praticamente na ponte aérea Brasil e Estados Unidos, passando a ser referência de um mestre que conseguiu o reconhecimento do seu trabalho, da sua arte, e se tornando um homem de sucesso, um baiano, um capoeirista que espantou o preconceito e encontrou o equilíbrio na simplicidade, espontaneidade e espiritualidade. No seu jeito de ser, filosofa dizendo: "a capoeira tem dois lados: o negativo e o positivo. Siga o positivo. Se você seguir o negativo, a capoeira sai do seu corpo"5.

Portanto, Mestre João Grande é, nos dias de hoje, um personagem importante na arte da capoeiragem, não apenas por ser um herdeiro de Mestre Pastinha, mas, principalmente, por dignificar a figura do mestre de capoeira e expandir a cultura afro-brasileira no mundo inteiro.

\footnotetext{
${ }^{1}$ Comunicação pessoal de Gildo Lemos Couto — "Mestre Gildo Alfinete" — na Disciplina da Educação, Cultura e Capoeira do Programa de Pós-graduação em Educação da FACED/UFBA, em 2002.

2 Ângelo Augusto Decanio Filho, médico e capoeirista, em entrevista no vídeo "O Velho Capoeirista: Mestre João Pequeno“, de Pedro Abib, Salvador, 1999.

${ }^{3}$ José Carlos Capinam, poeta e compositor baiano, em entrevista no vídeo "O Velho Capoeirista: Mestre João Pequeno", de Pedro Abib, Salvador, 1999.

${ }^{4}$ FEDERAÇÃO BAIANA DE CAPOEIRA, Boletim Informativo da Federação. Salvador: FBA, n.1, Ano 1, mar. 1990. 5 p. Edição histórica.

5 ZIGGIATTI, Manoela. João Grande foi à América mostrar a capoeira do Brasil. Universo Capoeira. São Paulo, nº 4 , p. 5-8, 1999.
} 